\title{
Post-traumatic stress and related symptoms in a gestation after a gestational loss: narrative review
}

\author{
Eloísa Fernández Ordóñez, ${ }^{1}$ Cristóbal Rengel Díaz, ${ }^{1,2}$ Isabel María Morales Gil, ${ }^{2}$ María Teresa Labajos Manzanares ${ }^{3}$
}

Hospital Universitario Virgen de la Victoria, Málaga, España.

2 Departamento de Enfermería, Universidad de Málaga, Málaga, España.

3 Departamento de Fisioterapia, Universidad de Málaga, Málaga, España.

\section{Correspondence:}

Eloísa Fernández Ordóñez

Calle Arquitecto Francisco Peñalosa, 3, 29071, Málaga, España.

Phone: 951952801

Email: eloisafdezordonez@gmail.com

Received: 17 March 2018

Accepted: 6 September 2018

\section{Citation:}

Fernández, E., Rengel, C., Morales, I. \& Labajos, M. (2018). Post-traumatic stress and related symptoms in a gestation after a gestational loss: narrative review. Salud Mental, 47 (5), 237-243, doi: $10.17711 /$ SM.0185-3325.2018.035

\section{(c) (i) $(5)$}

\begin{abstract}
Background. Around $30 \%$ of pregnancies conclude in a gestational loss. Most women who suffer a gestational loss become pregnant again. However, mothers who have experienced this situation live the new pregnancy with fear and anxiety. Objective. To perform an update of the main works done in the study of post-traumatic stress and related symptoms during pregnancy after a gestational loss. Method. The Medline database was consulted. Articles published from 2007 to date were selected. Key words related to the topic of study were used. Results. The studies reviewed showed five entities that deserve attention during a pregnancy achieved after a gestational loss: post-traumatic stress, depression, anxiety, relationship, and relationship with the future child. There is a relationship between the presence of post-traumatic stress and the risk of developing depression and anxiety. Discussion and conclusion. Women who experience perinatal loss, regardless of the type of loss and the gestational age in which it occurs, are at risk of continuing grief, symptoms of depression, anxiety, and post-traumatic stress in later pregnancy. The gestational age and the time elapsed between the perinatal loss and the next pregnancy seem to be the most influential factors in the development of post-traumatic stress sindrome, and symptoms of dysfunctional grief, anxiety, and depression.
\end{abstract}

Keywords: Mental health, perinatal loss, grief, pregnancy, post-traumatic stress disorders.

\section{RESUMEN}

Antecedentes. Alrededor de un $30 \%$ de los embarazos concluyen en una pérdida gestacional; de este porcentaje, la mayoría de las mujeres vuelve a quedar embarazada. Sin embargo quienes han experimentado esta situación viven con miedo y ansiedad su nuevo embarazo. Objetivo. Realizar una actualización de los principales trabajos realizados en cuanto al estudio del estrés postraumático y los síntomas relacionados con el embarazo posterior a una pérdida gestacional. Método. Se consultó la base de datos Medline y se seleccionaron artículos publicados desde 2007 hasta la fecha. Se emplearon palabras clave relacionadas con el tema de estudio. Resultados. Los estudios revisados mostraron cinco entidades que merecen atención durante un embarazo experimentado tras una pérdida gestacional: estrés postraumático, depresión, ansiedad, relación de pareja y vínculo con el futuro infante. Se encontró que existe una relación entre la presencia de estrés postraumático y el riesgo de desarrollar depresión y ansiedad. Discusión y conclusión. Las mujeres que experimentan pérdida perinatal, independientemente del tipo de pérdida y de la edad gestacional en la que se produce, corren el riesgo de continuar el duelo, los síntomas de depresión, la ansiedad y el estrés postraumático durante el embarazo posterior. La edad gestacional y el tiempo transcurrido entre la pérdida perinatal y el siguiente embarazo parecen ser los factores más influyentes en el desarrollo del síndrome de estrés postraumático, así como de síntomas de duelo disfuncional, ansiedad y depresión.

Palabras clave: Salud mental, pérdida perinatal, duelo, embarazo, trastornos por estrés postraumático. 


\section{BACKGROUND}

Around $30 \%$ of pregnancies result in a gestational loss. Gestational losses include spontaneous abortions, voluntary interruptions, fetal death, or early neonatal death. In the weeks after gestational loss, mothers experience sadness, irritability, or guilt, and such feelings can develop into chronic depression, hypochondria, phobias, or other pathologies. The high prevalence of symptoms of depression and anxiety suggests that they may be normal reactions. While most women experience normal grief reactions in response to gestational loss, about $25 \%-30 \%$ may have prolonged, intense, and complicated significant grief reactions that can negatively affect their psychological well-being. These reactions may be associated with the development of high levels of anxiety, depression, and post-traumatic stress (Bourne \& Lewis, 1984a; Hutti et al., 2017).

The severity of these symptoms usually diminishes during the first year, but it is common to see symptoms up to two years later. Approximately $20 \%$ of women show symptoms one year after the loss (Turton et al., 2006). Around $86 \%$ of women who suffer a gestational loss get pregnant again in the following 18 months (Gaudet, Séjourné, Camborieux, Rogers, \& Chabrol, 2010). However, pregnancies that occur after a gestational loss have received little interest on the part of the scientific community until a few decades ago (O’Leary, 2004), and do not receive special attention in clinical practice. It is common to find that these parents are still grieving over their loss instead of waiting joyfully for the arrival of a new baby. In these circumstances, death is closely linked to the experience of pregnancy, and it is common to live with the constant anxiety that this will happen again. Although depressive symptoms seem to decrease in some mothers after the birth of a healthy baby, high levels of distress have been reported in mothers of healthy babies who have previously suffered a gestational loss, with a high risk of depression. Parents often express mixed feelings towards the new baby. Puerperal reactions are often severe, and the risk seems to increase when reactions to the previous loss seemed minimal and a new pregnancy occurs rapidly (Bourne \& Lewis, 1984b). Post-traumatic stress related to previous gestational loss also influences depressive symptoms (Armstrong, 2007; Hutti, Armstrong, \& Myers, 2013).

Post-traumatic stress disorder (PTSD) is defined by the DSM-5 (American Psychiatric Association, 2013) as the change of the body's response to a stressful circumstance. For the World Health Organization (1992), trauma occurs when the person has been exposed to a threatening event or situation that could cause profound discomfort in almost everyone. The history of a traumatic event that poses a potential threat of death or serious injury gives rise to a response to this threat of feelings of fear or helplessness. Other criteria for PTSD involve the reaction to the traumatic event. There is a tendency to relive the experience, through flash- backs, for example. The person exhibits avoidance behavior and may also exhibit "hypervigilance" as it tries to ensure that the traumatic event does not recur, although it is always alert to the fact that it can happen again (Reynolds, 1997).

Turton, Hughes, Evans, and Fainman (2001) estimated that the lifetime risk of suffering PTSD for perinatal loss is 29\%; also, the risk of PTSD manifested in a subsequent pregnancy is 20\% (Turton \& Hughes, 2002). In turn, Hughes, Turton, Hopper, and Evans (2002) reported that approximately $20 \%$ of women who experience perinatal loss suffer from depression and another 20\% develop PTSD. It seems that the percentage of PTSD is higher during the first weeks after a gestational loss and that it decreases significantly with time, but not for all women. A variety of factors influences the development of PTSD sociodemographic characteristics such as maternal age, gestational age, educational level, background history of physical illness, or sexual trauma are factors to consider. It is advisable to postpone the pregnancy until the mother has completed the grieving process, since this may be complicated by the concern of the correct development of the future baby and its imminent birth. However, it is not uncommon to appreciate depressive symptoms during the next pregnancy (Bourne \& Lewis, 1984a).

Although pregnancies after gestational losses are frequent situations in clinical practice, in most cases there is no specific care for these women and their families. As these pathologies may imply risks for the mental health of the mother and for the link with the child, it is considered relevant to carry out this update for the holistic and multidisciplinary approach of these patients. The aim of this study is to make an update of the main work done in the study of post-traumatic stress and related symptoms such as anxiety, depression, and grief during pregnancy after a gestational loss and identify the risk factors for the development of these pathologies.

\section{METHOD}

For the integration of this review, the repertoire of Medline bibliographic references was taken as a basis. This unique database was selected as it is the most extensive medical bibliography database that exists.

The key words used were the terms MesH "stillbirth" and "stress disorders, post-traumatic". To complete the purpose of the search, the words "pregnancy loss" and "subsequent pregnancy" were added, which are widely found in the literature on this topic.

Two searches were conducted; in the first one, the keywords used were "stillbirth" and "stress disorders, post-traumatic" and "subsequent pregnancy", obtaining 21 references. Of this total of articles, two appeared in duplicate, and 11 were discarded after the reading of the title and the 
summary for not being related to the theme and the basis of this review. In the second search, the key words used were: "pregnancy loss" and "stress disorders, post-traumatic" and "subsequent pregnancy", and in this case only 18 references were obtained, of which only five were new and all were included due to their relevance with the aim of this study. For both searches, a time limit of 10 years and language limit of Spanish and English publications was established. No limit was set on the type of article, species, subset, text options, gender, or age. Two related articles were also included, which with the 13 articles selected above make a total of 15 articles (Figure 1).

For the selection of the studies, the following process was carried out: reading of the title, reading of the abstract,

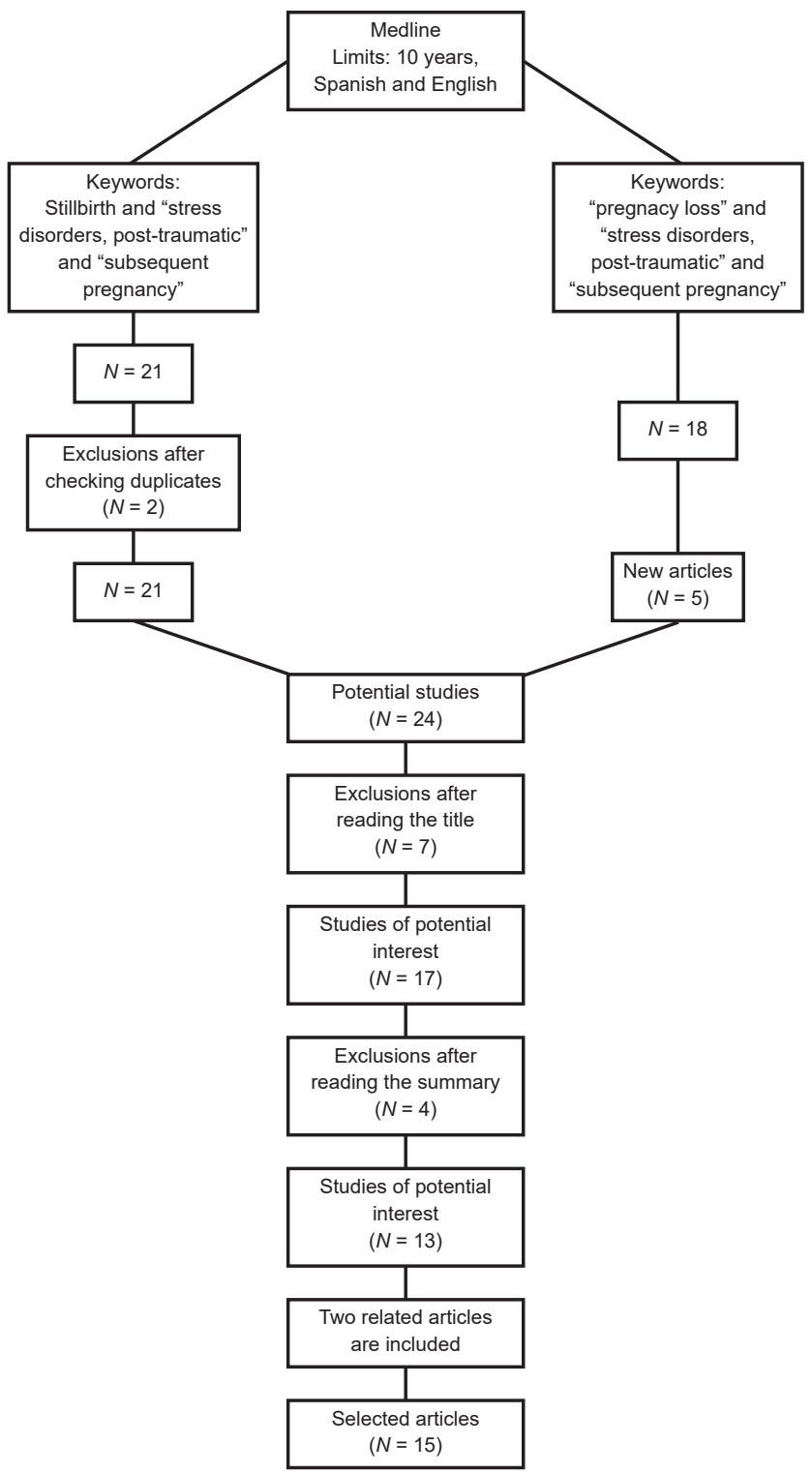

Figure 1. Flow chart. reading of the complete article, and selection of articles to be included. The exclusion criteria were: studies published more than 10 years ago, in a language other than English or Spanish, and which did not exceed the critical reading. Articles that did not meet the selection criteria established in the search strategy were discarded for the present review.

From the total of articles reviewed, a systematic review, four narrative reviews, a quasi-experimental study, three prospective studies, two descriptive studies, two meta-synthesis, and two qualitative studies were identified (Table 1).

The results obtained were grouped into five entities.

\section{RESULTS}

\section{Post-traumatic stress}

Higher levels of grief intensity were associated with an increase in pregnancy-specific anxiety $(r=.32, p<.0001)$ and depression symptoms $(r=.34, p<.0001)$. Similarly, the greater the intensity of the grief, the greater the post-traumatic stress related to perinatal loss measured by the total scale of the Impact of Event Scale (IES) $(r=.29, p<.0001)$. The longer duration of gestational age is associated with a higher probability of diagnosing post-traumatic stress disorder (Daugirdaitè, van den Akker, \& Purewal, 2015).

A greater intensity of grief was also associated with more intrusive thoughts, images, problematic dreams, strong emotions, and repetitive behavior that may be associated with perinatal loss measured by the Intrusion IES subscale $(r=.30, p<.0001)$, as well as the denial of the meaning and consequences of the loss measured by the IES Avoidance subscale $(r=.16, p<.05)$ (Hutti, Armstrong, Myers, \& Hall, 2015). Post-traumatic stress also influences depressive symptoms. Two thirds of the mothers were affected by the post-traumatic stress of the previous perinatal loss up to 12 months after the birth of a subsequent baby. An increase in the presence of post-traumatic stress disorder was observed when there was a short period of time between the loss and subsequent pregnancy (DeBackere, Hill, \& Kavanaugh, 2008).

\section{Grief}

The grief of the couples seemed to diminish with time, especially the feelings of sadness and guilt and the fear of possible future loss. The grief declined significantly from the beginning to three months and six months after a perinatal loss $(b=$ $7.75,10.84, p<.001)$ after controlling the independent variables. Although grief at 12 months after perinatal loss was significantly lower than at baseline $(b=9.55, p<.001)$, affliction did not differ significantly between 6-12 months after the loss (Daugirdaite et al., 2015; Rådestad, Hutti, Säflund, Onelöv, \& Wredling, 2010). The role, the gestational age of 
Table 1

Characteristics of the included studies

\begin{tabular}{|c|c|c|c|c|}
\hline Authors & Title & Type of study & Sample & Year \\
\hline $\begin{array}{l}\text { Tseng, Cheng, Chen, Yang, \& } \\
\text { Cheng (2017). }\end{array}$ & $\begin{array}{l}\text { Grief reactions of couples to perinatal loss: A } \\
\text { one-year prospective follow-up. }\end{array}$ & $\begin{array}{l}\text { A prospective follow-up } \\
\text { study }\end{array}$ & 60 couples & 2017 \\
\hline $\begin{array}{l}\text { Hunter, Tussis, \& MacBeth } \\
\text { (2017). }\end{array}$ & $\begin{array}{l}\text { The presence of anxiety, depression and } \\
\text { stress in women and their partners during } \\
\text { pregnancies following perinatal loss: A me- } \\
\text { ta-analysis. }\end{array}$ & Meta-analysis & 19 studies & 2017 \\
\hline $\begin{array}{l}\text { Meredith, Wilson, Branjerd- } \\
\text { porn, Strong, \& Desha (2017). }\end{array}$ & $\begin{array}{l}\text { "Not just a normal mum": a qualitative investi- } \\
\text { gation of a support service for women who are } \\
\text { pregnant subsequent to perinatal loss. }\end{array}$ & Qualitative analysis & 10 women & 2017 \\
\hline $\begin{array}{l}\text { Lisy, Peters, Riitano, Jordan, } \\
\text { \& Aromataris (2016). }\end{array}$ & $\begin{array}{l}\text { Provision of Meaningful Care at Diagnosis, } \\
\text { Birth, and after Stillbirth: A Qualitative Synthe- } \\
\text { sis of Parents' Experiences. }\end{array}$ & Meta- synthesis & 20 studies & 2016 \\
\hline $\begin{array}{l}\text { Wojceieszeck, Boyle, Belizan, } \\
\text { \& Cassidy (2016). }\end{array}$ & $\begin{array}{l}\text { Care in subsequent pregnancies following } \\
\text { stillbirth: An international survey of parents. }\end{array}$ & $\begin{array}{l}\text { Observational descriptive } \\
\text { study }\end{array}$ & 2716 parents & 2016 \\
\hline $\begin{array}{l}\text { Daugirdaité, van den Akker, \& } \\
\text { Purewal (2015). }\end{array}$ & $\begin{array}{l}\text { Posttraumatic Stress and Posttraumatic } \\
\text { Stress Disorder after Termination of Preg- } \\
\text { nancy and Reproductive Loss: A Systematic } \\
\text { Review. }\end{array}$ & Systematic review & 48 studies & 2015 \\
\hline $\begin{array}{l}\text { Hutti, Armstrong, Myers, \& } \\
\text { Hall (2015). }\end{array}$ & $\begin{array}{l}\text { Grief Intensity, Psychological Well-Being, and } \\
\text { the Intimate Partner Relationship in the Sub- } \\
\text { sequent Pregnancy after a Perinatal Loss. }\end{array}$ & $\begin{array}{l}\text { A correlational, descrip- } \\
\text { tive research design, } \\
\text { cross-sectional study }\end{array}$ & 227 pregnant women & 2015 \\
\hline $\begin{array}{l}\text { Campbell-Jackson, Bezance, } \\
\text { \& Horsch (2014). }\end{array}$ & $\begin{array}{l}\text { "A renewed sense of purpose": Mothers' and } \\
\text { fathers' experience of having a child following } \\
\text { a recent stillbirth. }\end{array}$ & $\begin{array}{l}\text { Interpretative phenome- } \\
\text { nological analysis }\end{array}$ & 7 couples & 2014 \\
\hline Mills et al. (2014). & $\begin{array}{l}\text { Parents' experiences and expectations of care } \\
\text { in pregnancy after stillbirth or neonatal death: } \\
\text { A metasynthesis. }\end{array}$ & Metasynthesis & 23 studies & 2014 \\
\hline $\begin{array}{l}\text { Hutti, Armstrong, \& Myers } \\
\text { (2013). }\end{array}$ & $\begin{array}{l}\text { Evaluation of the Perinatal Grief Intensity } \\
\text { Scale in the Subsequent Pregnancy After } \\
\text { Perinatal Loss. }\end{array}$ & Cross-sectional study & 227 pregnant women & 2013 \\
\hline $\begin{array}{l}\text { Avelin, Rädestad, Sáflund, } \\
\text { Wredling, \& Erlandsson (2013). }\end{array}$ & $\begin{array}{l}\text { Parental grief and relationship after the loss of } \\
\text { a stillborn baby. }\end{array}$ & $\begin{array}{l}\text { A prospective follow-up } \\
\text { study }\end{array}$ & $\begin{array}{l}55 \text { parents, } 33 \text { mothers } \\
\text { and } 22 \text { fathers }\end{array}$ & 2013 \\
\hline van der Akker (2011). & $\begin{array}{l}\text { The psychological and social consequences } \\
\text { of miscarriage. }\end{array}$ & Review & --- & 2011 \\
\hline $\begin{array}{l}\text { Rådestad, Hutti, Säflund, } \\
\text { Onelöv, \& Wredling (2010). }\end{array}$ & $\begin{array}{l}\text { Advice given by health-care professionals to } \\
\text { mothers concerning subsequent pregnancy } \\
\text { after stillbirth. }\end{array}$ & $\begin{array}{l}\text { A prospective follow-up } \\
\text { study }\end{array}$ & 57 women & 2010 \\
\hline Coleman (2009). & $\begin{array}{l}\text { The Psychological Pain of Perinatal Loss and } \\
\text { Subsequent Parenting Risks: Could Induced } \\
\text { Abortion be more Problematic than Other } \\
\text { Forms of Loss. }\end{array}$ & Review & --- & 2009 \\
\hline $\begin{array}{l}\text { DeBackere, Hill, \& Kavanaugh } \\
\text { (2008). }\end{array}$ & $\begin{array}{l}\text { The parental experience of pregnancy after } \\
\text { perinatal loss. }\end{array}$ & Review & 17 & 2008 \\
\hline
\end{tabular}

the deceased baby, infertility, religious beliefs, the number of live children, and marital satisfaction were significantly associated with the changes in grief over time. Women had significantly higher affliction scores than men $(b=9.35$, $p<.001$ ), but clinical levels of distress have also been reported in men. Parents who lost a baby after 20 or more weeks of gestation suffered a much more severe affliction ( $b=9.17, p=.011$ ) than parents who lost a baby after less than 20 weeks of gestation. Infertility was associated with a significantly higher grief score $(b=6.80, p=.026)$. Parents who had religious beliefs $(p=.031)$, live children $(p<.001)$, and a higher level of satisfaction within their relationship ( $p=.011)$ tended to have a lower grief score after the perinatal loss. If the parents had a previous perinatal loss or if one or both had a full-time job was not significantly associated with the grief score (Daugirdaite et al., 2015; Tseng, Cheng, Chen, Yang, \& Cheng, 2017).

\section{Anxiety}

The previous gestational loss significantly affected the experiences of the parents. Many felt deprived of the "normal" 
positive feelings they expected and described how their later pregnancies were characterized by increased anxiety and fear. As the risk of recurrence increases after the previous perinatal death, it is not surprising that parents were afraid of suffering another loss. However, anxiety and stress intensified with concrete experiences and at specific times during later pregnancies. Women often described increased agitation and worry as they approached the time of gestation in which they had lost their previous baby (Hunter, Tussis, \& MacBeth, 2017). Likewise, the result of routine appointments and ultrasounds was also associated with an increase in stress, related to the potential to discover a problem. The intense emotional reactions were precipitated by the suspicion or confirmation of a complication. The women repeatedly expressed doubts about their physical ability to maintain a successful pregnancy. In some cases, this "distrust" provoked requests for intervention (Lisy, Peters, Riitano, Jordan, \& Aromataris, 2016; Meredith, Wilson, Branjerdporn, Strong, \& Desha, 2017; Mills et al., 2014; Wojcieszek et al., 2016). The meta-analysis performed by Hunter et al. (2017) concludes a significant mean effect of perinatal loss on the increase of anxiety levels in women during subsequent pregnancies.

Higher levels of depression and anxiety have been observed in women who conceive quickly after a perinatal loss. Likewise, an anxious grief pattern after gestational loss is a risk factor for the development of depression during later pregnancy (van den Akker, 2011).

\section{Depression}

Significant moderate correlations were found for mothers and fathers with a history of perinatal loss when assessing the association of depressive symptoms and stress related to loss after the birth of a healthy baby $(r=.54, p<.001)$. As post-traumatic stress increased, levels of post-natal depressive symptoms also increased. For parents with a history of perinatal loss, the levels of depressive symptoms decreased significantly after the birth of a subsequent healthy baby. Although the depressive symptoms decreased for some mothers, high levels of distress persisted for many after birth. Approximately one third of mothers with a history of loss continued to report scores that placed them at high risk of depression (Hunter et al., 2017). Mothers, regardless of the type of loss, reported high levels of depression symptoms $(p<.001)$ in pregnancy following a previous perinatal loss. Similarly, using the IES total cut-score an indicator of post-traumatic stress, all the scores of the average loss group were significantly higher than 23 (range 34.4 - 35.5, $p<.001)$. The groups of losses differed significantly in their scores on the subscale Impact of Intrusion of Events and the subscale Impact of Event Evasion. Tukey's post hoc test showed that mothers who experienced a neonatal death had a higher average score on the Intrusion Scale than mothers who experienced a miscarriage $(p<.001)$. Mothers who had a miscarriage scored significantly higher on the Avoidance subscale compared to those in the neonatal death group ( $p<$ .018). No other pairwise comparison was significant (Hutti et al., 2015).

\section{Couple relationships}

After three months, $91 \%$ of mothers and $64 \%$ of fathers thought that the loss had an influence on their relationship. Some mothers thought that this loss brought them closer to their partner, but $82 \%$ of the women did not think they were suffering for the lost baby in the same way as their partner. After one year, almost $60 \%$ of mothers said they understood their partner's way of coping, and during a year, $58 \%$ of mothers said they could talk openly about the event with their partner. After two years, $89 \%$ of the mothers and $93 \%$ of the fathers considered that they were experiencing the loss in a different way (Tseng et al., 2017). Hutti et al. (2015) also found an association between the quality of the intimate relationship prior to perinatal loss and the intensity of grief symptoms so that the worse the quality of the relationship, the greater the intensity of grief $(r=-.25, p=.001)$ in pregnancy after a loss (Avelin, Rädestad, Säflund, Wredling, \& Erlandsson, 2013). In the link with the new baby, negative emotions can delay attachment during subsequent pregnancy. Attachment difficulties are logical after the loss of a pregnancy (Coleman, 2009). Some mothers expressed a hesitant link with the new baby. Pain from a previous loss may arise during later pregnancies, observing mothers more detached or on the contrary more overprotective with the unborn baby (Meredith et al., 2017; Tseng, Chen, \& Wang, 2014). A poor prenatal involvement has been associated with more maladaptive outcomes (Meredith et al., 2017). The replacement syndrome has been described as a set of parental implications in mothers who became pregnant quickly after a perinatal loss. In these cases, parents usually have problems of unresolved grief (Coleman, 2009).

\section{DISCUSSION AND CONCLUSION}

In clinical practice, it is common to find pregnancies occurring after a perinatal loss, be this due to abortion, voluntary interruption, antenatal death, or early neonatal death.

Women who experience perinatal loss, regardless of the type of loss and the gestational age in which it occurs, are at risk of continuing grief, symptoms of depression, anxiety, and post-traumatic stress in later pregnancy.

The gestational age and the time elapsed between the perinatal loss and the next pregnancy seem to be the most influential factors in the development of post-traumatic stress sindrome and symptoms of dysfunctional grief, anxiety, and depression. In turn, the presence of any of these reactions seems to influence the existence of some others. 
Similarly, feelings of anxiety and depression interfere with the quality of the attachment with the new creature for fear of a new loss. In general, there is consensus in the scientific literature that a pregnancy after a perinatal loss is experienced with feelings of anxiety and hypervigilance (Reid, 2007). The results obtained in this review coincide with most of the studies consulted that have studied these symptoms after a gestational loss (Christiansen, 2017; Burden et al., 2016; Krosch \& Shakespeare-Finch, 2017; Ridaura, Penelo, \& Raich, 2017).

More scarce are the studies that analyze these consequences in pregnancies that take place after a gestational loss, with similar results (Al-Maharma, Abujaradeh, Mahmoud, \& Jarrad, 2016; Brooten et al., 2015; Chojenta et al., 2014; Üstündağ-Budak, Larkin, Harris, \& Blissett, 2015).

The symptoms of anxiety decrease as the pregnancy progresses in the confidence that this new pregnancy will conclude favorably, and in general this fosters the bond with the future baby (Cǒté-Arsenault, 2007).

Recently, Wonch, Cacciatore, Shreffler, and Pritchard (2017) have also reported lower levels of self-esteem in women who have suffered a gestational loss than in those who have not. Some authors recommend postponing the next pregnancy until the complete resolution of the duel (Rådestad et al., 2010), although others claim that the pain of perinatal loss never disappears (O’Leary \& Warland, 2012). To the scant interest that pregnancies following a perinatal loss have meant for research until only a few decades ago, we must add the fact that in most cases they do not receive the special attention they deserve (O'Leary, 2009).

There are experiences in adapted care for pregnancies that occur after a gestational loss with good results after psychosocial support to mothers and fathers who have suffered this circumstance. Support groups seem to be especially useful (Campbell-Jackson, Bezance, \& Horsch, 2014; Mills et al., 2014).

It is important that all health professionals who interact with mothers or fathers who have suffered a perinatal loss to do so using solidarity, empathy, patience, and respect (Bennett, Litz, Lee, \& Maguen, 2005). It is necessary to bear in mind that control visits and routine procedures can trigger traumatic memories that can be a source of anguish (O'Leary, 2005).

The data obtained allow us to infer that gestational losses can lead to a wide range of pathologies related to mental health. In most cases they are ignored by health professionals. These sequelae can condition the experience of a subsequent pregnancy, which is not usually conveniently attended to. Perinatal grief is a complex construct involving multiple variables related to both the loss itself and the characteristics of the person who suffers. There are no conclusive results about the existence of factors associated with the risk of post-traumatic stress or related symptoms during a pregnancy after a gestation- al loss, so more studies are needed to guide a preventive strategy for these cases.

As a conclusion, we consider that it is important that obstetrical professionals become aware of the existence of these pathologies. It is important to highlight the importance of the detection of these symptoms by making use of the anamnesis. The convenient referral to mental health professionals would facilitate an early diagnosis, minimizing the consequences that these pathologies might have on the health of the mother and the newborn.

\section{Funding}

None.

\section{Conflict of interests}

The authors declare they have no conflict of interests.

\section{REFERENCES}

American Psychiatric Association. (2013). Diagnostic and statistical manual of mental disorders (DSM-5®). Arlington: American Psychiatric Publishing.

Al-Maharma, D. Y., Abujaradeh, H., Mahmoud, K. F., \& Jarrad, R. A. (2016). Maternal grieving and the perception of an atachment to children born subsequent to a perinatal loss. Infant Mental Health Journal, 37(4), 411-423. doi: 10.1002/ imhj. 21570

Armstrong, D. S. (2007). Perinatal loss and parental distress after the birth of a healthy infant. Advances in Neonatal Care, 7(4), 200-206. doi: 10.1097/01. ANC.0000286337.90799.7d

Avelin, P., Rädestad I., Säflund K., Wredling R., \& Erladsson K. (2013). Parental grief and relationship after the lost of a stillborn baby. Midwifery, 29(6), 668-673.

Bennett, S. M., Litz, B. T., Lee, B. S., \& Maguen, S. (2005). The Scope and Impact of Perinatal Loss: Current Status and Future Directions. Professional Psychology: Research and Practice, 36(2), 180-187. doi: 10.1037/0735-7028.36.2.180

Bourne, S. \& Lewis, E. (1984a). Pregnancy after stillbirth or neonatal death. The Lancet, 2(8393), 31-33. doi: 10.1016/S0140-6736(84)92011-7

Bourne, S. \& Lewis, E. (1984b). Delayed psychological effects of perinatal deaths: The next pregnancy and the next generation. British Medical Journal, 289(6438), 147-148.

Brooten, D., Youngblut, J. M., Hannan, J., Caicedo, C., Roche, R., \& Malkawi, F. (2015). Infant and child deaths: Parent concerns about subsequent pregnancies. Journal of the American Association of Nurse Practitioners, 27(12), 690-697. doi: 10.1002/2327-6924.12243

Burden, C., Bradley, S., Storey, C., Ellis, A., Heazell, A. E. P., Downe, S., ... Siassakos, D. (2016). From grief, guilt pain and stigma to hope and pride - A systematic review and meta-analysis of mixed-method research of the psychosocial impact of stillbirth. BMC Pregnancy and Childbirth, 16(9), 1-12. doi: 10.1186/ s12884-016-0800-8

Campbell-Jackson, L., Bezance, J., \& Horsch, A. (2014). "A renewed sense of purpose": Mothers' and fathers' experience of having a child following a recent stillbirth. BMC Pregnancy and Childbirth, 14(1), 423. doi: 10.1186/s12884-014-0423-x

Chojenta, C., Harris, S., Reilly, N., Forder, P., Austin, M.-P., \& Loxton, D. (2014). History of Pregnancy Loss Increases the Risk of Mental Health Problems in Subsequent Pregnancies but Not in the Postpartum. PLoS ONE, 9(4), e95038. doi: 10.1371/journal.pone.0095038

Christiansen, D. M. (2017). Posttraumatic stress disorder in parents following infant death: A systematic review. Clinical Psychology Review, 51, 60-74. doi: 10.1016/j.cpr.2016.10.007

Coleman, P. K. (2009). The Psychological Pain of Perinatal Loss and Subsequent Parenting Risks: Could Induced Abortion be more Problematic than Other Forms of Loss. Current Women's Health Reviews, 5(2), 88-99. doi: $10.2174 / 157340409788185785$ 
Cǒté-Arsenault, D. (2007). Threat appraisal, coping, and emotions across pregnancy subsequent to perinatal loss. Nursing Research, 56(2), 108-116. doi: 10.1097/01. NNR.0000263970.08878.87

Daugirdaitè, V., van den Akker, O., \& Purewal, S. (2015). Posttraumatic Stress and Posttraumatic Stress Disorder after Termination of Pregnancy and Reproductive Loss: A Systematic Review. Journal of Pregnancy, 2015, 1-14. doi: $10.1155 / 2015 / 646345$

DeBackere, K. J., Hill, P. D., \& Kavanaugh, K. L. (2008). The parental experience of pregnancy after perinatal loss. Journal of Obstetric, Gynecologic, and Neonatal Nursing, 37(5), 525-537. doi: 10.1111/j.1552-6909.2008.00275.x

Gaudet, C., Séjourné, N., Camborieux, L., Rogers, R., \& Chabrol, H. (2010). Pregnancy after perinatal loss: association of grief, anxiety and attachment. Journal of Reproductive and Infant Psychology, 28(3), 240-251. doi: 10.1080/02646830903487342

Hughes, P., Turton, P., Hopper, E., \& Evans, C. (2002). Assessment of guidelines for good practice in psychosocial care of mothers after stillbirth: a cohort study. The Lancet, 360(9327), 114-118. doi: 10.1016/S0140-6736(02)09410-2

Hunter, A., Tussis, L., \& MacBeth, A. (2017). The presence of anxiety, depression and stress in women and their partners during pregnancies following perinatal loss: A meta-analysis. Journal of Affective Disorders, 223(1),153-164. doi: 10.1016/j.jad.2017.07.004

Hutti, M. H., Armstrong, D. S., \& Myers, J. (2013). Evaluation of the Perinatal Grief Intensity Scale in the Subsequent Pregnancy After Perinatal Loss. Journal of Obstetric, Gynecologic \& Neonatal Nursing, 42(6), 697-706. doi: 10.1111/1552-6909.12249

Hutti, M. H., Armstrong, D. S., Myers, J. A., \& Hall, L. A. (2015). Grief Intensity, Psychological Well-Being, and the Intimate Partner Relationship in the Subsequent Pregnancy after a Perinatal Loss. Journal of Obstetric, Gynecologic, \& Neonatal Nursing, 44(1), 42-50. doi: 10.1111/1552-6909.12539

Hutti, M. H., Myers, J., Hall, L. A., Polivka, B. J., White, S., Hill, J., ... Grisanti, M. M. (2017). Predicting grief intensity after recent perinatal loss. Journal of Psychosomatic Research, 101, 128-134. doi: 10.1016/j.jpsychores.2017.07.016

Krosch, D. \& Shakespeare-Finch, J. (2017). Grief, traumatic stress, and posttraumatic growth in women who have experienced pregnancy loss. Psychological Trauma: Theory, Research, Practice, and Policy, 9(4), 425-433. Retrieved from http://web.b.ebscohost.com.iris.etsu.edu:2048/ehost/pdfviewer/pdfviewer?vid= 9\&sid=003f901c-b8bb-4ae0-87a0-cc2f54a62386\%40sessionmgr101

Lisy, K., Peters, M. D. J., Riitano, D., Jordan, Z., \& Aromataris, E. (2016). Provision of Meaningful Care at Diagnosis, Birth, and after Stillbirth: A Qualitative Synthesis of Parents' Experiences. Birth, 43(1), 6-19. doi: 10.1111/birt.12217

Meredith, P., Wilson, T., Branjerdporn, G., Strong, J., \& Desha, L. (2017). "Not just a normal mum": A qualitative investigation of a support service for women who are pregnant subsequent to perinatal loss. BMC Pregnancy and Childbirth, 17(1), 6. doi: 10.1186/s12884-016-1200-9

Mills, T. A., Ricklesford, C., Cooke, A., Heazell, A. E. P., Whitworth, M., \& Lavender, T. (2014). Parents' experiences and expectations of care in pregnancy after stillbirth or neonatal death: A metasynthesis. BJOG: An International Journal of Obstetrics and Gynaecology, 121(8), 943-950. doi: 10.1111/1471-0528.12656

O'Leary, J. (2004). Grief and its impact on prenatal attachment in the subsequent pregnancy. Archives of Women's Mental Health, 7(1), 7-18. doi: 10.1007/ s00737-003-0037-1

O'Leary, J. (2005). The trauma of ultrasound during a pregnancy following perinatal loss. Journal of Loss and Trauma, 10(2), 183-204. doi: $10.1080 / 15325020590908876$
O'Leary, J. (2009). Never a simple journey: Pregnancy following perinatal loss. Bereavement Care, 28(2), 12-17. doi: 10.1080/02682620902996004

O’Leary, J. \& Warland, J. (2012). Intentional Parenting of Children Born After a Perinatal Loss. Journal of Loss and Trauma, 17(2), 137-157. doi: 10.1080/15325024.2011.595297

Rådestad, I., Hutti, M., Säflund, K., Onelöv, E., \& Wredling, R. (2010). Advice given by health-care professionals to mothers concerning subsequent pregnancy after stillbirth. Acta Obstetricia et Gynecologica Scandinavica, 89(8), 1084-1086. doi: $10.3109 / 00016341003657926$

Reid, M. (2007). The loss of a baby and the birth of the next infant: The mother's experience. Journal of Child Psychotherapy, 33(2), 181-201. doi: 10.1080/00754170701431339

Reynolds, J. L. (1997). Post-traumatic stress disorder after childbirth: The phenomenon of traumatic birth. Canadian Medical Association, 156(6),831-835.

Ridaura, I., Penelo, E., \& Raich, R. M. (2017). Sintomatología depresiva y duelo en mujeres españolas que han sufrido una pérdida perinatal. Psicothema, 29(1), 43-48. doi: 10.7334/psicothema2016.151

Tseng, Y. F., Chen, C. H., \& Wang, H. H. (2014). Taiwanese women's process of recovery from stillbirth: A qualitative descriptive study. Research in Nursing and Health, 37(3), 219-228. doi: 10.1002/nur.21594

Tseng, Y. F., Cheng, H. R., Chen, Y. P., Yang, S. F., \& Cheng, P. T. (2017). Grief reactions of couples to perinatal loss: A one-year prospective follow-up. Journal of Clinical Nursing, 26(23-24), 5133-5142. doi: 10.1111/jocn.14059

Turton, P., Badenhorst, W., Hughes, P., Ward, J., Riches, S., \& White, S. (2006). Psychological impact of stillbirth on fathers in the subsequent pregnancy and puerperium. The British Journal of Psychiatry, 188(1), 165-72. doi: 10.1192/ bjp.188.2.165

Turton, P. \& Hughes, P. (2002). Post-traumatic stress disorder and management of stillbirth. The British Journal of Psychiatry, 180(3), 279. doi: 10.1192/ bjp.180.3.279

Turton, P., Hughes, P., Evans, C. D. H., \& Fainman, D. (2001). Incidence, correlates and predictors of post-traumatic stress disorder in the pregnancy after stillbirth. The British Journal of Psychiatry, 178(6), 556-560. doi: 10.1192/bjp.178.6.556

Üstündağ-Budak, A. M., Larkin, M., Harris, G., \& Blissett, J. (2015). Mothers' accounts of their stillbirth experiences and of their subsequent relationships with their living infant: An interpretative phenomenological analysis. BMC Pregnancy and Childbirth, 15(1), 263. doi: 10.1186/s12884-015-0700-3

van den Akker, O. B. (2011). The psychological and social consequences of miscarriage. Expert Review of Obstetrics \& Gynecology, 6(3), 295-304. doi: 10.1586/ eog. 11.14

Wojcieszek, A. M., Boyle, F. M., Belizan, J. M., Cassidy, J., Cassidy, P., Erwich, J. J. H. M., ... Mills, T. (2016). Care in subsequent pregnancies following stillbirth: An international survey of parents. BJOG: An International Journal of Obstetrics and Gynaecology, 125(2) 193-201. doi: 10.1111/1471-0528.14424

Wonch, P., Cacciatore, J., Shreffler, K. M., \& Pritchard, K. M. (2017). The loss of self: The effect of miscarriage, stillbirth, and child death on maternal self-esteem. Death Studies, 41(4), 226-235. doi: 10.1080/07481187.2016.1261204

World Health Organization. (1992). The ICD-10 classiffication of mental and behavioural disorders: Clinical descriptions and diagnostic guidelines. Geneva: World Health Organization. 